\title{
Detailed macro- and micromineral profile of milk: Effects of herd productivity, parity, and stage of lactation of cows of 6 dairy and dual-purpose breeds
}

\author{
G. Stocco, ${ }^{1,2}$ A. Summer, ${ }^{2}$ M. Malacarne, ${ }^{2}$ A. Cecchinato, ${ }^{1 *}$ and G. Bittante ${ }^{1}$ \\ ${ }^{1}$ Department of Agronomy, Food, Natural Resources, Animals and Environment, University of Padova, viale dell'Università 16, \\ 35020 Legnaro (PD), Italy \\ ${ }^{2}$ Department of Veterinary Science, University of Parma, via del Taglio 10, 43126 Parma, Italy
}

\section{ABSTRACT}

The aim of this study was to quantify the major sources of variation in the levels of 15 minerals in individual milk samples collected from cows raised in multibreed dairy herds. The herds $(\mathrm{n}=27)$ were classified into 2 categories, according to milk productivity. Milk productivity was based on the net energy of lactating cows' average daily milk yield. Milk samples were collected from 240 cows of 6 different breeds: 3 specialized dairy (Holstein-Friesian, Brown Swiss, and Jersey) and 3 dual-purpose (Simmental, Rendena, and Alpine Grey). The samples were analyzed for macroelements ( $\mathrm{Na}, \mathrm{Mg}, \mathrm{P}, \mathrm{S}, \mathrm{K}$, and $\mathrm{Ca}$ ), essential microelements ( $\mathrm{Mn}, \mathrm{Fe}, \mathrm{Cu}, \mathrm{Zn}$, and $\mathrm{Se}$ ), and environmental micro-elements (B, Si, Sr, and Sn), using inductively coupled plasma-optical emission spectrometry. Data were analyzed using a linear mixed model that included fixed effects of days in milk (DIM), parity, breed, and herd productivity, and a random effect of herd-date within productivity level. Results showed that the effect of herd-date varied across minerals. It was especially large for environmental minerals (ranging from 47 to $91 \%$ of total variance) and ranged from 11 to $61 \%$ for macrominerals and essential microminerals. Milk samples collected from farms with a high level of herd productivity had a richer mineral profile than samples from low-productivity herds. Parity only influenced macrominerals, with the exception of $\mathrm{S}$ and $\mathrm{Ca}$, while DIM influenced almost all minerals, with a few exceptions among the environmental elements. Differences in mineral profile were small between specialized and dual-purpose breeds, but they were large within the group of the specialized cows. These breed differences were reduced after adjusting for milk quality and yield, particularly in the case of milk $\mathrm{Mg}, \mathrm{S}, \mathrm{Ca}, \mathrm{Mn}$, and $\mathrm{Zn}$

Received April 20, 2019

Accepted July 11, 2019.

*Corresponding author: alessio.cecchinato@unipd.it levels. Milk samples from the Jersey and Brown Swiss cows had higher mineral levels (Sn excluded) than milk from the Holstein-Friesian cows; the other breeds of Alpine origin produced milk of intermediate quality. Our findings suggest that breed has a stronger effect on macrominerals and some of the essential microminerals than herd productivity, parity, and DIM. The modification of the mineral profile in milk seems possible for many minerals, but it likely depends on genetics (e.g., breed, selection) and on environmental and management factors in variable proportions according to the mineral considered.

Key words: Holstein-Friesian, Brown Swiss, Jersey, local breeds, trace minerals

\section{INTRODUCTION}

Cow milk is a valuable source of minerals (Cashman, 2002, 2006; Zamberlin et al., 2012), even though minerals constitute a small proportion of milk composition (about 8-9 g/L). Milk contains a wide variety of minerals (Perween, 2015) occurring in different chemical forms, including inorganic ions and salts, or linked to proteins, nucleic acids, fats, and carbohydrates (Cashman, 2006). Global demand for fortified dairy products is growing as consumers are paying increasingly more attention to the nutritional composition of foods. Some studies have reported that minerals have better functional effects when combined with each other (Huth et al., 2006) or with other nutrients, such as vitamins, proteins, and fatty acids (Soyeurt et al., 2009). However, studies on minerals in milk (especially $\mathrm{Ca}, \mathrm{P}$, and $\mathrm{Mg}$ ) have generally been carried out to assess their effects on human health and on milk technological properties, particularly with regard to cheese-making efficiency (Cooke and McSweeney, 2014; Gustavsson et al., 2014; Malacarne et al., 2014). In addition, some elements, including $\mathrm{Na}$ and $\mathrm{K}$, have been studied in terms of their role in the diagnosis of specific diseases in dairy cows, such as mastitis (Hamann and Krömker, 1997; Summer et al., 2009). 
The mineral content of milk seems to depend, first of all, on feeding practices for lactating females (Gulati et al., 2018), although for some macrominerals (i.e., $\mathrm{Ca}, \mathrm{K}, \mathrm{Mg}$ ), genetic factors play a much more important role in the variation between individual cows (van Hulzen et al., 2009; Gaignon et al., 2018). The complex relationships between feed content, gastrointestinal microbiome activity, absorption, and animal metabolism and requirements and the antagonisms and toxicity of several minerals in dairy cows were reviewed by the National Research Council (NRC, 2001) when nutrient requirements for dairy cattle were established. Since then, many other studies have been published and new information has become available, as reviewed by Spears and Weiss (2014).

As aforementioned, the level of some minerals in milk is affected by cow genetics, with variation found both across breeds and within breed (Buitenhuis et al., 2015). Few studies have dealt with the genetics of the mineral composition of milk (van Hulzen et al., 2009; Buitenhuis et al., 2015), in particular because of the large number of individual milk samples that would need to be analyzed and the consequent costs. The use of indirect predictions, such as those based on infrared spectroscopy, provides results with variable accuracy (Soyeurt et al., 2009; Stocco et al., 2016; Malacarne et al., 2018) and needs further evaluation. However, in a study to estimate genetic parameters and detect quantitative trait loci for minerals in 456 Danish Holstein and 436 Danish Jersey cows, Buitenhuis et al. (2015) showed that the minerals in milk, in particular $\mathrm{Ca}, \mathrm{P}$, $\mathrm{Mg}$, and $\mathrm{Zn}$, have high heritability $(0.57,0.62,0.60$, and 0.41 , respectively). In addition, Tsiamadis et al. (2016) showed that essential macrominerals in the blood serum of dairy cows have moderate to high heritability (from 0.12 to 0.43 ).

More information is available regarding the effect of breed on the mineral profile of milk, but results often pertain to only a few minerals and are limited by a lack of comparison across different dairy farming systems, although they do account for different parities and lactation stages. Further, the studies that compare different breeds are mostly based on either a small number of cows of 2 to 3 different breeds, reared at 1 or 2 (experimental) farms (Mariani et al., 2002; Summer et al., 2004), or a large number of cows kept mainly on single-breed farms (van Hulzen et al., 2009). Consequently, the effects of breed on mineral elements could be confounded with the effects of farm, feeding strategy, and sampling date. Moreover, the large majority of published studies focus on macromineral elements, while microminerals in milk and dairy products receive much less attention (Coni et al., 1995, 1996; van Hulzen et al., 2009).
For these reasons, we carried out a large study involving several multibreed herds characterized by 2 different levels of milk productivity, thereby allowing for independent evaluation of the effects of farm and different cattle breeds on the detailed composition of milk. The general aim of this research was to analyze, using a holistic approach, the major sources of variation of the level of 15 macro- and microminerals in milk, using inductively coupled plasma-optical emission spectrometry (ICP-OES). In particular, our specific aims were to (1) analyze the effect of high versus low herd productivity; (2) quantify the variability of different herds within herd productivity class; (3) describe the effects of DIM and parity of individual cows on the mineral profile of milk; (4) carry out a within-herd comparison of 3 dairy and 3 dual-purpose breeds of cows; and (5) disentangle the direct effect of breed on milk mineral content from the indirect effect of breed due to differences in milk yield and composition.

\section{MATERIALS AND METHODS}

\section{Multibreed Herds}

The present study was carried out as part of the Cowplus project. A total of 1,508 cows from 41 multibreed herds (2-5 breeds per herd, average 3$)$ located in the Trentino-Alto Adige region in the northeastern Italian Alps, were evaluated once for daily milk production and sampled during an evening milking for milk quality analysis. Details on the characteristics of farms, the cows, and the milk sampling method are included in previous studies from the same project, together with the results obtained on milk yield, composition, and coagulation properties (Stocco et al., 2017); milk nutrients recovery in curd and cheese yield (Stocco et al., 2018); and association with udder health traits (Bobbo et al., 2017). The environmental context was described by Bittante et al. (2015), and the genetic background of the major breeds involved was reported by Cecchinato et al. (2015).

We analyzed the mineral composition of milk from a subsample of 240 cows from 27 multibreed herds containing 6 different breeds. These cows and herds were selected with the aim of balancing the different factors affecting milk production and quality, particularly herd productivity class, breed, parity, and DIM, and avoiding possible confounding effects. The study included 3 specialized dairy breeds: Holstein-Friesian (50 cows from 15 herds, parity $2.9 \pm 1.8$, and DIM $162 \pm 88 \mathrm{~d}$ ); Brown Swiss (50 cows from 16 herds, parity at $2.7 \pm$ 1.8 , and DIM $164 \pm 85 \mathrm{~d}$ ), and Jersey (35 cows from 7 herds, parity $2.8 \pm 1.9$, and DIM $170 \pm 90 \mathrm{~d}$ ). The study also included 3 dual-purpose breeds: Simmental 
(35 cows from 11 herds, parity $2.6 \pm 1.7$, and DIM 163 $\pm 88 \mathrm{~d}$ ), Rendena (34 cows from 8 herds, parity $2.4 \pm$ 1.5, and DIM $159 \pm 91 \mathrm{~d}$ ), and Alpine Grey (34 cows from 9 herds, parity $2.6 \pm 1.7$, and DIM $167 \pm 36 \mathrm{~d}$ ), the latter 2 being autochthonous breeds.

\section{Classification of Herd Productivity}

Two categories of herd productivity (HP, high and low) were defined according to the daily milk energy output (dMEO) of the lactating cows. The net energy required for lactation (NEL) is the energy contained in the milk produced. The NEL concentration in milk is equivalent to the sum of the heats of combustion of individual milk components (fat, protein, and lactose), as reported by NRC (2001) and estimated using the following equation:

$$
\begin{gathered}
\text { NEL }(\text { Mcal } / \mathrm{kg})=0.0929 \times \text { fat, } \%+0.0547 \\
\times \text { protein, } \%+0.0395 \times \text { lactose }, \%,
\end{gathered}
$$

where NEL is the energy of $1 \mathrm{~kg}$ milk. The NEL values obtained were converted to $\mathrm{MJ} / \mathrm{kg}$ and multiplied by the daily milk yield of each cow $(\mathrm{MJ} / \mathrm{d})$ to obtain the dMEO of each cow. Individual dMEO data were subjected to an ANOVA using the GLM procedure in SAS (SAS Institute Inc., Cary, NC) to obtain the least squares means (LSM) of the dMEO for the selected herds after correcting for breed, DIM, and parity of the cows. The 27 herds were ranked according to the LSM of their dMEO and then classified based on the median value as high producing (high-HP: $\mathrm{n}=13$, dMEO $=82.41 \mathrm{MJ} / \mathrm{d}$ ) or low producing (low-HP: $\mathrm{n}=14$, $\mathrm{dMEO}=50.63 \mathrm{MJ} / \mathrm{d})$.

Large-framed breeds (Holstein-Friesian, Brown Swiss, and Simmental) were found in both high- and lowproductivity herds, Jerseys only in high-productivity herds, and local breeds (Rendena and Alpine Grey) only in low-productivity herds.

\section{Analysis of Milk Samples}

Milk samples (without preservative) were cooled to $4^{\circ} \mathrm{C}$ immediately after collection and processed within $24 \mathrm{~h}$ of sampling at the Milk Quality Laboratory of the Department of Agronomy, Food, Natural Resources, Animals and Environment of the University of Padova.

All samples were analyzed for SCC (Fossomatic Minor, Electric A/S, Hillerød, Denmark), and SCC value was log-transformed to SCS. Protein and fat content was measured with a MilkoScan FT2 infrared analyzer (Foss Electric A/S), calibrated according to reference methods (ISO 8968-2/IDF 20-2 for protein, ISO-IDF,
2014; ISO 1211/IDF for fat, ISO-IDF, 2010). The daily milk yield $(\mathrm{kg} / \mathrm{d})$ of each cow was recorded as the total yield of morning plus evening milkings.

A Spectro Arcos EOP ICP-OES (Spectro A.I. GmbH, Kleve, Germany) was used to determine 15 elements: $\mathrm{Na}, \mathrm{Mg}, \mathrm{P}, \mathrm{S}, \mathrm{K}, \mathrm{Ca}, \mathrm{Mn}, \mathrm{Fe}, \mathrm{Cu}, \mathrm{Zn}, \mathrm{Se}, \mathrm{B}, \mathrm{Si}, \mathrm{Sr}$, and Sn. Another 16 minerals were below the instrumental limit of detection in all or a large proportion of the milk samples, and they were therefore not considered for statistical analysis. When individual milk samples had a concentration for a given mineral below the limit of detection, a value equal to half the limit itself was assigned (Croghan and Egeghy, 2003).

All operating parameters of the ICP-OES equipment were optimized for nitric acid $10 \%$ solution as follows: axial plasma observation; Crossflow nebulizer; Scott Double Pass spray chamber; 3.0-mm-diameter quartz injector torch; plasma power, 1,400 W; coolant gas, $12.0 \mathrm{~L} / \mathrm{min}$; auxiliary gas, $0.6 \mathrm{~L} / \mathrm{min}$; nebulizer gas, $0.85 \mathrm{~L} / \mathrm{min}$; additional gas, $0.20 \mathrm{~L} / \mathrm{min}$; sample uptake rate, $2.0 \mathrm{~mL} / \mathrm{min}$; replicate read time, $28 \mathrm{~s} ; 3$ replicates; and pre-flush time, $60 \mathrm{~s}$. Milk samples were analyzed after microwave closed-vessel digestion (Ethos 1600 Milestone S.r.l., Sorisole, BG, Italy). Subsamples of between 1.950 and $2.050 \mathrm{~g}$ of milk were taken from each sample and placed in a tetrafluormethaxil vessel with $2 \mathrm{~mL}$ of $30 \%$ hydrogen peroxide and $7 \mathrm{~mL}$ of concentrated (65\%) nitric acid, both Suprapur quality (Merck Chemicals GmbH, Darmstadt, Germany). These prepared subsamples were subjected to microwave digestion as follows: step 1,25 to $200^{\circ} \mathrm{C}$ in $18 \mathrm{~min}$ at $1,500 \mathrm{~W}$ with $\mathrm{P} \max 4,500,000 \mathrm{~Pa}$; step $2,200^{\circ} \mathrm{C}$ for 15 min at $1,500 \mathrm{~W}$ with $\mathrm{P} \max 4,500,000 \mathrm{~Pa}$; and step 3,200 to $110^{\circ} \mathrm{C}$ in $15 \mathrm{~min}$. After cooling to room temperature, the dissolved sample was diluted with ultrapure water (resistivity $18.2 \mathrm{M} \Omega \cdot \mathrm{cm}$ at $25^{\circ} \mathrm{C}$ ) to a final volume of $20 \mathrm{~mL}$. Calibration standards were prepared using multi-element and single-element standard solutions (Inorganic Ventures Inc., Christiansburg, VA) in $10 \%$ Suprapur nitric acid (Merck Chemicals GmbH) to obtain matrixes similar to the samples. Concentrations of $0,0.002,0.005,0.02,0.05,0.2,0.5$, and $2 \mathrm{mg} / \mathrm{L}$ of the analytes were prepared. The concentrations of the calibration solutions for macrominerals $(\mathrm{Ca}, \mathrm{K}, \mathrm{Mg}, \mathrm{Na}$, $\mathrm{P}$, and S) were as for the other analytes plus 5, 20, 50, and $200 \mathrm{mg} / \mathrm{L}$, respectively. The accuracy and precision of both methods were tested by analyzing a blank solution, a low-level control solution (recovery limits \pm $30 \%$ ), a medium-level control solution (recovery limits $\pm 10 \%$ ), and the international standard reference material BCR-063R "skim milk powder" (Institute for Reference Materials and Measurements, Geel, Belgium), prepared as described above. The measured values and the certified values were in excellent agreement for all 
the minerals certified in the standard reference materials (i.e., skim milk powder).

To improve readability of the results, we decided to group minerals as macro-elements $(\mathrm{Na}, \mathrm{Mg}, \mathrm{P}, \mathrm{S}, \mathrm{K}$, and $\mathrm{Ca}$ ) and micro-elements, with the latter subdivided into essential micro-elements ( $\mathrm{Mn}, \mathrm{Fe}, \mathrm{Cu}, \mathrm{Zn}$, and $\mathrm{Se})$ and micro-elements that result from environmental contamination but do not play a specific role in animal metabolism (B, Si, Sr, and Sn).

\section{Statistical Analysis}

Experimental data were analyzed using the MIXED procedure (SAS) according to the following model (base model):

$$
\begin{aligned}
y_{\text {mnopqr }}= & \mu+\operatorname{HP}_{m}+\operatorname{Herd}_{n}\left(\mathrm{HP}_{m}\right)+\text { Breed }_{o} \\
& + \text { Parity }_{p}+\text { DIM }_{q}+e_{\text {mnopqr }},
\end{aligned}
$$

where $y_{\text {mnopqr }}$ is the observed trait (milk yield, protein, fat, and SCS; Na, Mg, P, S, K, Ca, Mn, Fe, Cu, Zn, Se, $\mathrm{B}, \mathrm{Si}, \mathrm{Sr}$, and $\mathrm{Sn}) ; \mu$ is the overall intercept of the model; $H P_{m}$ is the fixed effect of the $m$ th herd productivity ( $m=2$ levels); Herd $n$ is the random effect of the $n$th herd $(n=1$ to 27$)$ within the $m$ th class of herd productivity; Breed $_{o}$ is the fixed effect of the oth breed ( $o=$ Holstein-Friesian, Brown Swiss, Jersey, Simmental, Rendena, and Alpine Grey); Parity is the fixed effect of the $p$ th parity $(p=1$ to $\geq 3$; class 1 , first parity [80 samples]; class 2 , second parity [59 samples]; class 3 , third or greater parity [99 samples]); $D I M_{q}$ is the fixed effect of the $q$ th class of days in milk $(q=1-8$; class 1, 8-49 d [25 samples]; class 2, 50-91 d [27 samples]; class 3, 92-133 d [39 samples]; class 4, 134-175 d [42 samples]; class 5, 176-217 d [43 samples]; class 6, 156-259 d [32 samples]; class 7, 186-301 d [18 samples]; class $8,>301 \mathrm{~d}\left[12\right.$ samples]); $e_{\text {mnopqr }}$ is the random residual $\sim N\left(0, \sigma_{e}^{2}\right)$. The HP effect was tested on the $\operatorname{Herd}(H P)$ error line, while the other factors were tested on the residual variance.

Orthogonal contrasts were estimated between the LSM of the traits for the effect of breed: (1) specialized dairy (Holstein-Friesian, Brown Swiss, and Jersey) versus dual-purpose breeds (Simmental, Rendena, and Alpine Grey); (2) within specialized, large-framed versus small-framed breeds (Holstein-Friesian + Brown Swiss vs. Jersey); (3) comparison of the 2 large-framed dairy breeds (Holstein-Friesian vs. Brown Swiss); (4) within dual-purpose, large-framed breed versus mediumframed local breeds (Simmental vs. Rendena + Alpine Grey); and (5) comparison between the 2 mediumframed local dual-purpose breeds (Rendena vs. Alpine Grey). Orthogonal contrasts were also estimated be- tween the LSM of the traits for the effect of parity: (1) first versus second and greater and (2) second versus third and greater; and for the effect of DIM: (1) linear, (2) quadratic, and (3) cubic trends.

A further model (extended model) was used to analyze the direct effects of breed on mineral elements corrected for milk yield and quality traits. It was obtained from the base model with the addition of linear covariates of milk yield, fat, protein, and SCS. The indirect effect of breed on the minerals due to breed differences in terms of milk yield and quality was obtained by subtracting the breed variance yielded by the extended model from the breed variance yielded by the base model (with breed as random effect). Both direct and indirect breed variances were expressed as percentages of total breed variance.

\section{RESULTS}

\section{Milk Mineral Profile and Effects of Herd Productivity}

Of the 31 minerals analyzed, 11 were above the limit of detection in all milk samples, 4 were detected in the majority of milk samples, and 16 were mainly below the limit of detection in all or almost all the milk samples and therefore not included in the analysis. Descriptive statistics of the levels of the 15 mineral elements detected and of the milk yield, protein, and fat content and SCS of the samples are summarized in Table 1. The minerals exhibited large variability due to the many sources of variability included in this study (herd productivity class, individual herds, 6 breeds, parity, and lactation stage).

Least squares means of HP class, $F$-values, and levels of significance are shown in Table 2. Milk yield was obviously very different in the $2 \mathrm{HP}$ levels, and milk protein content was also higher in the high-HP class than in in the low-HP class, whereas the differences in milk fat and SCS did not reach significance due to their greater residual variability.

With regard to macrominerals, milk samples from high-HP farms had greater levels of $\mathrm{Mg}, \mathrm{S}$, and Ca than milk samples from low-HP farms. Among the essential microminerals, $\mathrm{Cu}$ and $\mathrm{Zn}$ were greater for high-HP farms. No effect of HP on environmental microminerals was observed.

Table 2 also shows the variability among the different herds within the HP classes expressed as the proportion of herd/test date variance on total variance. Of the macrominerals, $\mathrm{P}$ and $\mathrm{S}$ exhibited wide variability across the different herds (more than other milk traits), $\mathrm{Mg}$ and Ca had intermediate variability (similar to that of milk traits), and $\mathrm{Na}$ and $\mathrm{K}$ showed low variability (similar to that of SCS). Among essential microminer- 
Table 1. Descriptive statistics of milk yield, composition, and mineral contents

\begin{tabular}{|c|c|c|c|c|c|c|}
\hline Item & Atomic N & $\mathrm{N}$ & Mean & $\mathrm{SD}$ & Minimum & Maximum \\
\hline Protein, $\%$ & - & 238 & 3.59 & 0.44 & 2.77 & 4.85 \\
\hline Fat, \% & - & 238 & 4.23 & 1.20 & 1.02 & 7.97 \\
\hline \multicolumn{7}{|c|}{ Macrominerals, $\mathrm{mg} / \mathrm{kg}$} \\
\hline $\mathrm{Na}$ & 11 & 235 & 334 & 67 & 252 & 646 \\
\hline $\mathrm{Mg}$ & 12 & 233 & 101 & 15 & 70 & 156 \\
\hline $\mathrm{K}$ & 19 & 233 & 1,527 & 167 & 1,230 & 1,995 \\
\hline $\mathrm{Ca}$ & 20 & 234 & 1,274 & 156 & 940 & 1,758 \\
\hline \multicolumn{7}{|c|}{ Essential microminerals, $\mu \mathrm{g} / \mathrm{kg}$} \\
\hline $\mathrm{Mn}$ & 25 & 237 & 24 & 10 & 6 & 66 \\
\hline $\mathrm{Fe}$ & 26 & 237 & 261 & 82 & 131 & 645 \\
\hline $\mathrm{Cu}$ & 29 & 236 & 45 & 38 & 13 & 234 \\
\hline $\mathrm{Zn}$ & 30 & 238 & 4,126 & 991 & 2,502 & 5,845 \\
\hline Sn & 50 & 238 & 271 & 318 & 35 & 2,743 \\
\hline
\end{tabular}

${ }^{1} \mathrm{SCS}=3+\log _{2}(\mathrm{SCC} / 100,000)$.

als, Mn and Se exhibited high herd variability; Fe and $\mathrm{Cu}$, intermediate; and $\mathrm{Zn}$, low. Environmental microminerals all exhibited very high variability among the different herds/sampling dates. This high variability may also be the main reason for the nonsignificance of the HP effect, despite the large differences between the

Table 2. Effect of class of herd productivity and of parity on milk yield, composition, and mineral contents

\begin{tabular}{|c|c|c|c|c|c|c|c|c|c|c|}
\hline \multirow[b]{2}{*}{ Item } & \multicolumn{3}{|c|}{ Herd productivity (HP) } & \multirow{2}{*}{$\begin{array}{c}\text { Herd } \\
\text { (within HP) } \\
\text { (\% of total } \\
\text { variance) }\end{array}$} & \multicolumn{3}{|c|}{ Parity (LSM) } & \multicolumn{2}{|c|}{$\begin{array}{l}\text { Parity contrasts } \\
\quad(F \text {-value })\end{array}$} & \multirow[b]{2}{*}{$\mathrm{RMSE}^{1}$} \\
\hline & $\begin{array}{c}\text { High-HP } \\
\text { (LSM) }\end{array}$ & $\begin{array}{l}\text { Low-HP } \\
\text { (LSM) }\end{array}$ & $F$-value & & 1 & 2 & $\geq 3$ & 1 vs. $\geq 2$ & 2 vs. $\geq 3$ & \\
\hline Milk yield, $\mathrm{kg} / \mathrm{d}$ & 24.0 & 14.9 & $51.1^{* * *}$ & 23.7 & 17.8 & 19.9 & 20.7 & $13.8^{* * *}$ & 0.9 & 4.6 \\
\hline Protein, \% & 3.74 & 3.54 & $8.8^{*}$ & 25.5 & 3.67 & 3.65 & 3.59 & 2.3 & 2.8 & 0.2 \\
\hline Fat, $\%$ & 4.50 & 4.15 & 2.5 & 19.1 & 4.37 & 4.27 & 4.33 & 0.3 & 0.2 & 0.9 \\
\hline $\mathrm{Na}$ & 359 & 361 & 0.0 & 12.0 & 341 & 360 & 379 & $27.7^{* * *}$ & $9.1^{* *}$ & 39 \\
\hline $\mathrm{Mg}$ & 108 & 101 & $8.1^{* *}$ & 17.6 & 107 & 104 & 101 & $9.0^{* *}$ & 3.3 & 8 \\
\hline $\mathrm{P}$ & 1,041 & 993 & 2.6 & 40.8 & 1,055 & 1,006 & 990 & $22.2^{* * *}$ & 1.3 & 51 \\
\hline $\mathrm{S}$ & 268 & 253 & $5.3^{*}$ & 33.8 & 263 & 263 & 258 & 0.5 & 1.6 & 14 \\
\hline $\mathrm{K}$ & 1,675 & 1,690 & 0.5 & 10.6 & 1,697 & 1,691 & 1,661 & 2.1 & 3.4 & 70 \\
\hline $\mathrm{Ca}$ & 1,261 & 1,204 & $4.9^{*}$ & 22.4 & 1,237 & 1,234 & 1,225 & 0.2 & 0.4 & 68 \\
\hline \multicolumn{11}{|c|}{$\begin{array}{l}\text { Essential microminerals, } \\
\mu \mathrm{g} / \mathrm{kg}\end{array}$} \\
\hline $\mathrm{Se}$ & 112 & 96 & 0.9 & 49.2 & 102 & 105 & 105 & 0.2 & 0.0 & 41 \\
\hline \multicolumn{11}{|c|}{$\begin{array}{l}\text { Environmental } \\
\text { microminerals, } \mu \mathrm{g} / \mathrm{kg}\end{array}$} \\
\hline B & 186 & 210 & 1.4 & 67.5 & 198 & 200 & 196 & 0.1 & 0.5 & 27 \\
\hline $\mathrm{Si}$ & 699 & 882 & 0.9 & 46.9 & 763 & 824 & 783 & 0.3 & 0.2 & 484 \\
\hline $\mathrm{Sr}$ & 296 & 298 & 0.0 & 78.1 & 288 & 306 & 297 & 2.3 & 0.7 & 63 \\
\hline Sn & 526 & 262 & 2.4 & 90.6 & 410 & 393 & 379 & 1.2 & 0.3 & 142 \\
\hline
\end{tabular}

${ }^{1} \mathrm{RMSE}=$ root mean squared error.

${ }^{2} \mathrm{SCS}=3+\log _{2}(\mathrm{SCC} / 100,000)$.

${ }^{*} P<0.05 ;{ }^{* *} P<0.01 ;{ }^{* * *} P<0.001$. 
LSM of the $2 \mathrm{HP}$ classes, given that herd variance was taken as the error line for testing the HP effect.

\section{Effects of Parity and DIM}

The effect of parity (Table 2) on production traits was limited to the greater daily milk production and SCS of multiparous compared with primiparous cows.

With regard to mineral content, milk from primiparous cows had higher levels of $\mathrm{Mg}, \mathrm{P}$, and $\mathrm{Cu}$ than milk from multiparous cows. The opposite pattern was observed for $\mathrm{Na}$ content, which increased not only from the first to second lactation, but also to the third and subsequent lactations. The concentrations of environmental minerals did not differ across parities.

Variation in the levels of the 15 minerals in milk analyzed throughout lactation (corrected for all other sources of variation included in the statistical model) was highly significant for all the essential macro- and microminerals, except for Se, while among the environmental microminerals, only $\mathrm{B}$ was affected by lactation stage (data not shown). Figure 1 shows that among the macrominerals, the concentrations of $\mathrm{Na}$ was characterized by a cubic pattern, with an increase mainly during the middle phase of lactation, while $\mathrm{K}$ tended to decrease (quadratic pattern) during the second phase of lactation. Increases in $\mathrm{P}$ and $\mathrm{Ca}$ (Figure 2) were almost linear $(\mathrm{P})$ or curvilinear $(\mathrm{Ca})$ during the lactation period ( $10 \%$ for $\mathrm{P}$ and $6 \%$ for $\mathrm{Ca}$, from the first to the last class of DIM). The levels of both $\mathrm{Mg}$ and $\mathrm{S}$ in milk increased almost linearly during the lactation period, by 13 and $17 \%$, respectively (Figure 3).

Among the essential microminerals, the Fe content of milk increased linearly by about $27 \%$ during lactation, while $\mathrm{Cu}$ had a curvilinear trend, decreasing rapidly at first then increasing toward the end of lactation (Figure

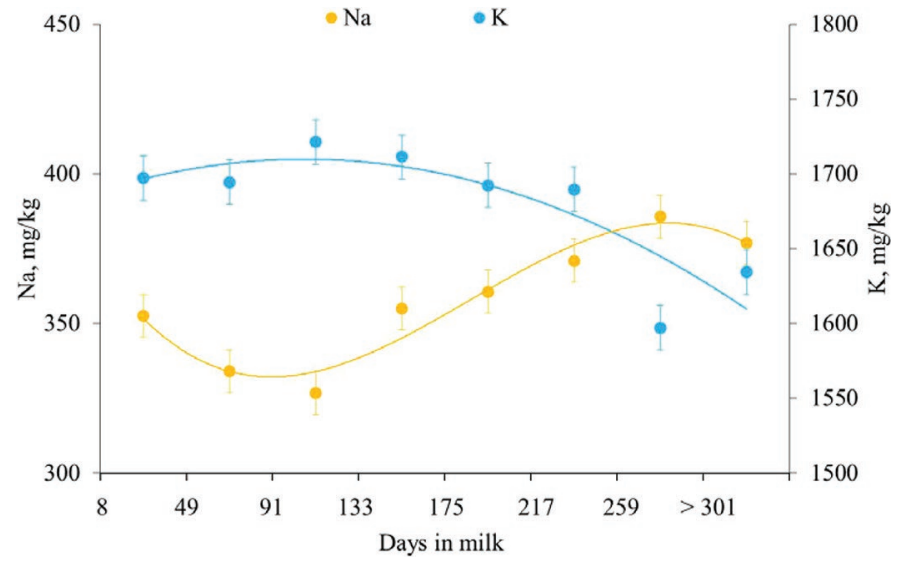

Figure 1. Milk content of $\mathrm{Na}(P<0.001)$ and $\mathrm{K}(P<0.001)$ during lactation. Error bars represent SE.

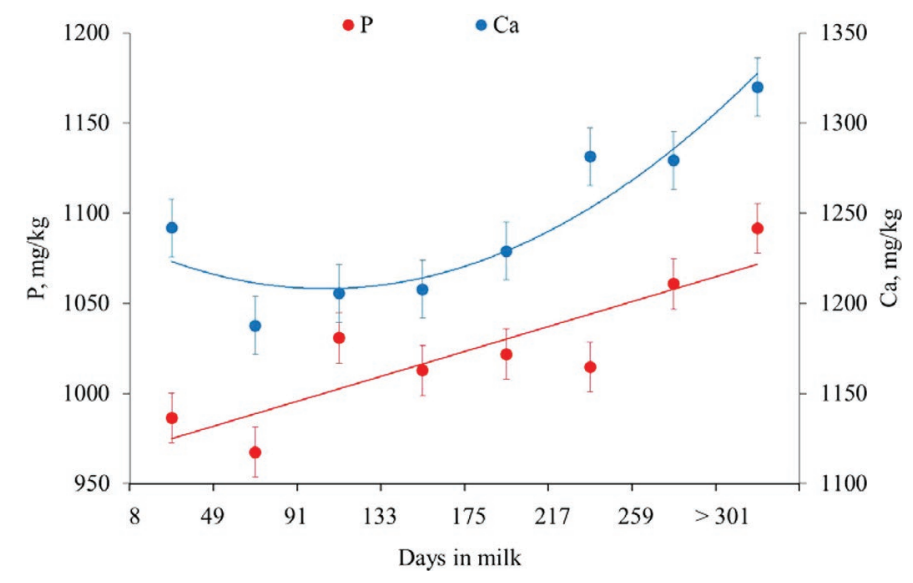

Figure 2. Milk content of $\mathrm{P}(P<0.001)$ and $\mathrm{Ca}(P<0.001)$ during lactation. Error bars represent SE.

4). Given that about half the milk samples had a $\mathrm{Cu}$ content below the instrumental limit of detection, we considered $\mathrm{Cu}$ as a dichotomous trait $(0=$ below the limit of detection, 1 = above the limit of detection) in a parallel statistical analysis. We found that the proportion of these samples out of all the milk samples exhibited a pattern very similar to that observed for $\mathrm{Cu}$ content (data not shown) used as a continuous trait (i.e., by assigning a value equal to half the limit itself). The Mn and Se content of milk exhibited different patterns (Figure 5); the former increased almost linearly by about $48 \%$, while the latter decreased during lactation by about $24 \%$ (nonsignificant). The Zn content exhibited a cubic pattern, with a decrease during the first third of lactation and an increase thereafter (Figure 6), while an almost opposite cubic pattern was observed for $\mathrm{B}$, the only environmental micromineral that exhibited variation during lactation.

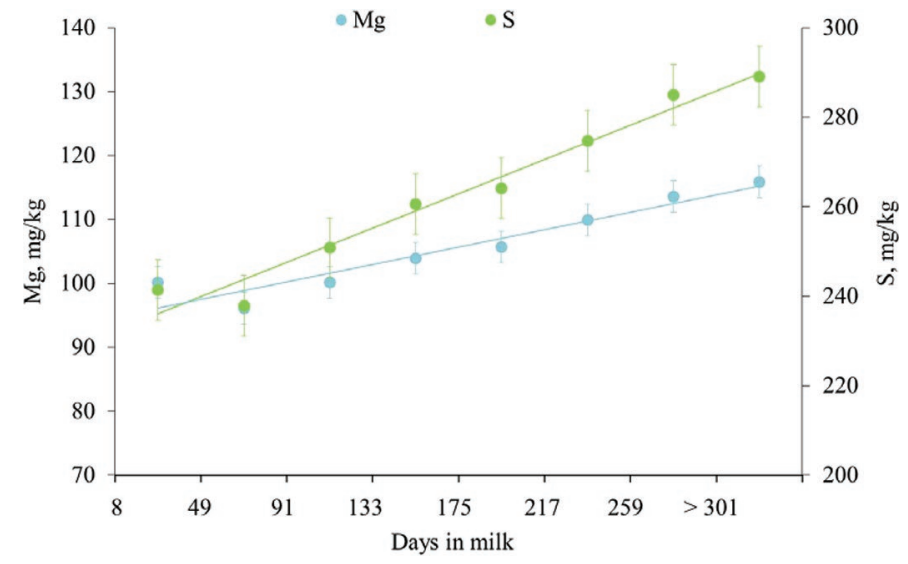

Figure 3. Milk content of $\mathrm{Mg}(P<0.001)$ and $\mathrm{S}(P<0.001)$ during lactation. Error bars represent SE. 


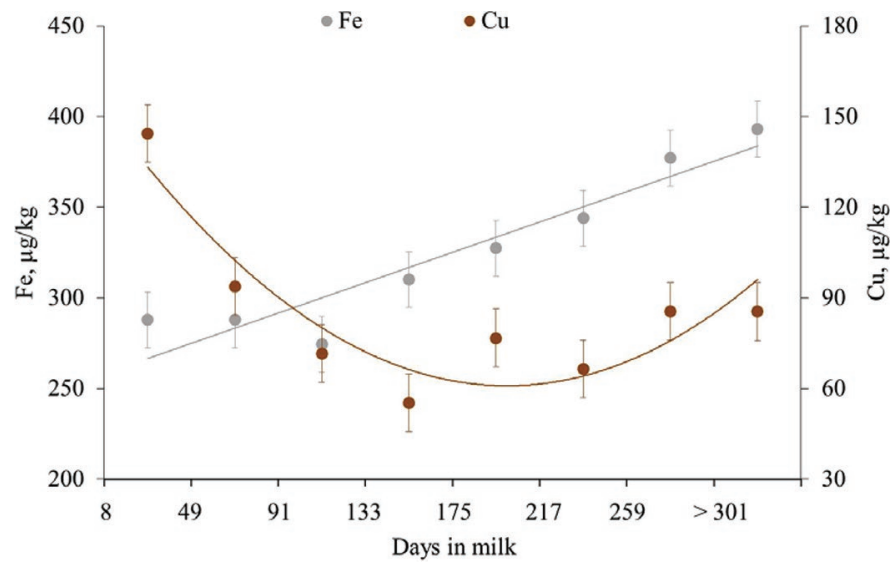

Figure 4. Milk content of $\mathrm{Fe}(P<0.001)$ and $\mathrm{Cu}(P<0.001)$ during lactation. Error bars represent SE.

\section{Effects of Breed}

Least squares means of the effects of breed and their orthogonal contrasts ( $F$-value) for all the observed traits are reported in Table 3. A comparison of the group of 3 specialized dairy breeds (Holstein-Friesian, Brown Swiss, and Jersey) with the dual-purpose breeds (Simmental, Rendena, and Alpine Grey) reveals that orthogonal comparisons were seldom significant because the differences were large between breeds in each group. In fact, milk yield also did not reach statistical difference. Regarding milk quality traits, specialized dairy breeds, on average, out-yielded dual-purpose breeds in the protein and fat content of their milk. In general, the productive aptitude of cows did not affect the levels of any of the mineral elements, except for $\mathrm{P}$, which was higher in the dual-purpose breeds, and Se and Sr, which were higher in the specialized dairy breeds.

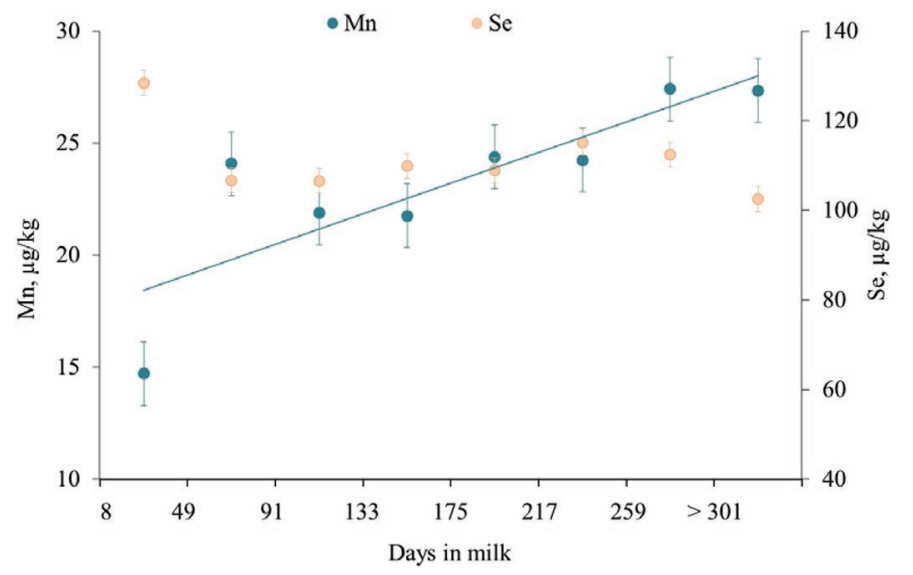

Figure 5. Milk content of Se and Mn $(P<0.001)$ during lactation. Error bars represent SE.
Very large differences were observed among the 3 specialized dairy breeds for milk production and for the majority of the minerals analyzed, while much smaller differences were found among the 3 dual-purpose breeds (Table 3). In particular, comparison of the smallframed breed (Jersey) with the 2 large-framed breeds (Holstein-Friesian and Brown Swiss) confirmed that the former has a lower productive potential than the latter breeds (daily milk yield $-37 \%$ ), but also higher milk protein $(+13 \%)$ and fat $(+33 \%)$ content and lower SCS. Milk from Jersey cows had higher levels of the macrominerals $\mathrm{Mg}(+8 \%), \mathrm{S}(+9 \%)$, and $\mathrm{Ca}(+10 \%)$; a lower level of $\mathrm{K}(-5 \%)$; and much higher levels of the essential micro-elements Mn, Zn, and Se than HolsteinFriesian and Brown Swiss milk (Table 3). Among the environmental micro-elements, only the level of B differed, being lower in milk from Jersey cows than in milk from the 2 large-framed dairy breeds.

Between the 2 large-framed dairy breeds, Brown Swiss cows were found to have a lower productivity potential $(-17 \%)$ than Holstein-Friesians, compensated by a greater milk protein content $(+12 \%)$ and higher percentages of $\mathrm{Mg}(+6 \%), \mathrm{P}(+9 \%), \mathrm{S}(+13 \%)$, and $\mathrm{Ca}$ $(+6 \%)$ among the macro-elements, and much higher percentages of $\mathrm{Mn}(+36 \%), \mathrm{Fe}(+23 \%)$, and $\mathrm{Zn}(+24 \%)$ among the essential microminerals. Of the environmental microminerals, only Simmental differed in the 2 large dairy breeds (higher in Brown Swiss milk).

With regard to dual-purpose breeds, the largeframed Simmental cows produced, on average, more milk $(+30 \%)$ than the 2 medium-framed local breeds (Rendena and Alpine Grey), and milk with a greater fat content $(+16 \%)$. The only differences found between the Simmentals and the averages of the 2 local breeds in the mineral content of their milk involved $\mathrm{Na}(-5 \%)$ and $\mathrm{Sr}(+64 \%)$. Last, the only differences

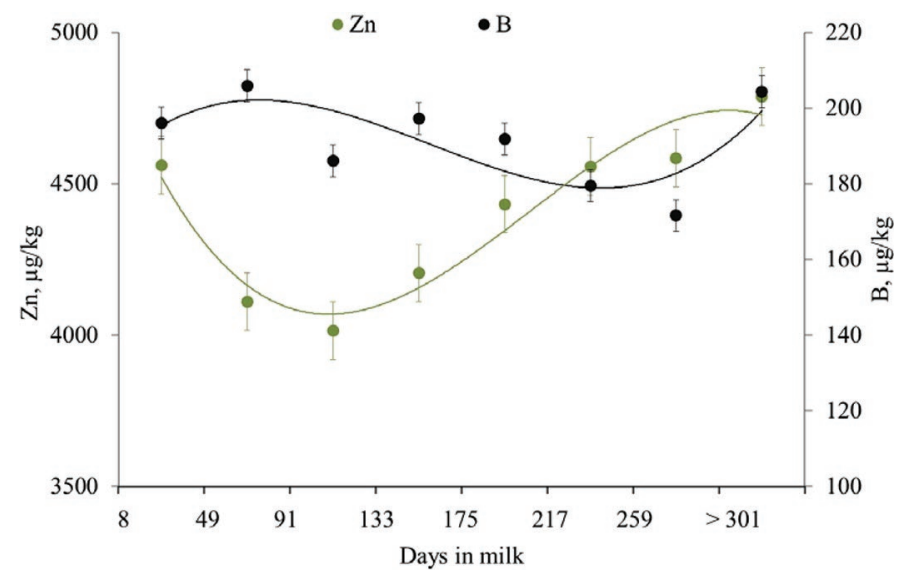

Figure 6. Milk content of $\mathrm{Zn}(P<0.01)$ and B $(P<0.05)$ during lactation. Error bars represent SE. 
Table 3. Effect of breed of cows on milk yield, composition, and mineral contents

\begin{tabular}{|c|c|c|c|c|c|c|c|c|c|c|c|}
\hline Item & \multicolumn{6}{|c|}{ Breed $^{1}$ of cows (LSM) } & \multicolumn{5}{|c|}{ Breed contrast ( $F$-value) } \\
\hline Milk yield, $\mathrm{kg} / \mathrm{d}$ & 24.3 & 20.2 & 14.7 & 22.8 & 17.9 & 16.9 & 0.5 & $46.1^{* * *}$ & $14.2^{* *}$ & $21.5^{* * *}$ & 0.4 \\
\hline Protein, \% & 3.35 & 3.75 & 4.02 & 3.60 & 3.43 & 3.68 & $9.8^{* *}$ & $66.9^{* * *}$ & $50.7^{* * *}$ & 0.6 & $10.0^{* *}$ \\
\hline Fat, $\%$ & 4.08 & 4.10 & 5.45 & 4.52 & 3.73 & 4.05 & $7.6^{*}$ & $43.5^{* * *}$ & 0.0 & $8.7^{*}$ & 1.3 \\
\hline $\mathrm{Na}$ & 358 & 366 & 356 & 347 & 375 & 358 & 0.0 & 0.6 & 0.8 & $5.1^{*}$ & 2.3 \\
\hline $\mathrm{Mg}$ & 100 & 106 & 110 & 104 & 101 & 103 & 1.6 & $10.5^{* *}$ & $7.8^{*}$ & 1.1 & 0.6 \\
\hline $\mathrm{P}$ & 941 & 1,024 & 1,016 & 1,049 & 1,016 & 1,053 & $8.7^{*}$ & 2.8 & $17.3^{* * *}$ & 0.4 & 1.7 \\
\hline $\mathrm{S}$ & 241 & 273 & 281 & 263 & 244 & 266 & 3.5 & $23.5^{\text {*** }}$ & $45.9^{* * *}$ & 2.3 & $8.8^{* *}$ \\
\hline $\mathrm{K}$ & 1,687 & 1,711 & 1,617 & 1,689 & 1,699 & 1,693 & 1.7 & $14.6^{* * *}$ & 1.3 & 0.2 & 0.1 \\
\hline $\mathrm{Ca}$ & 1,169 & 1,244 & 1,321 & 1,251 & 1,207 & 1,201 & 1.8 & $23.2^{* * *}$ & $10.6^{* *}$ & 3.7 & 0.3 \\
\hline $\mathrm{Cu}$ & 72 & 91 & 100 & 72 & 91 & 82 & 0.2 & 2.3 & 2.2 & 1.1 & 0.3 \\
\hline $\mathrm{Zn}$ & 3,673 & 4,554 & 4,693 & 4,555 & 4,245 & 4,291 & 0.2 & $14.9^{* * *}$ & $34.9^{* * *}$ & 3.5 & 0.1 \\
\hline $\mathrm{Se}$ & 98 & 98 & 152 & 93 & 94 & 90 & $8.4^{* *}$ & $25.7^{* * *}$ & 0.0 & 0.0 & 0.1 \\
\hline \multicolumn{12}{|l|}{$\begin{array}{l}\text { Environmental } \\
\text { microminerals, } \\
\mu \mathrm{g} / \mathrm{kg}\end{array}$} \\
\hline $\mathrm{B}$ & 200 & 214 & 184 & 209 & 184 & 195 & 0.2 & $7.3^{* *}$ & 2.5 & 3.9 & 0.8 \\
\hline $\mathrm{Si}$ & 685 & 979 & 831 & 894 & 824 & 528 & 0.7 & 0.0 & $5.8^{*}$ & 2.7 & 2.7 \\
\hline $\mathrm{Sr}$ & 290 & 318 & 323 & 332 & 256 & 266 & $5.1^{*}$ & 1.7 & 3.3 & $19.5^{* * *}$ & 0.2 \\
\hline Sn & 398 & 362 & 370 & 382 & 464 & 390 & 1.5 & 0.1 & 0.9 & 1.2 & 1.7 \\
\hline
\end{tabular}

${ }^{1} \mathrm{HF}=$ Holstein Friesian; BS = Brown Swiss; Je = Jersey; Sim = Simmental; Re = Rendena, AG = Alpine Grey

${ }^{2} \mathrm{SCS}=3+\log _{2}(\mathrm{SCC} / 100,000)$.

${ }^{*} P<0.05 ;{ }^{* *} P<0.01 ;{ }^{* * *} P<0.001$.

found between the 2 local breeds involved the Rendena cows producing milk with less protein $(-7 \%)$ and less $\mathrm{S}(-8 \%)$.

\section{DISCUSSION}

\section{Effects of the Environment on the Mineral Profile of Milk}

We are not aware of any previous research that has adopted a holistic approach to studying the contemporary effects of different environmental (e.g., production level, feeding, management, facilities) and physiological (e.g., breed, parity, lactation stage) conditions on the levels of many macro- and microminerals in the milk of many cows reared in different herds. The large majority of studies in the literature pertain to specific single issues (e.g., experimental diets testing, 2- to 3-breed comparison) on few elements, often macrominerals, which makes direct comparison with our results difficult. To enable better comparison of our results with findings from the scientific literature, we did not consider studies based on indirect predictions (e.g., infrared spectrometry) instead of specific laboratory methods because of the very large differences in methodology and accuracy of results.

The present study's findings regarding the detailed mineral profile of milk revealed large differences in the effects of different sources of variation among the 3 main groups of minerals examined: essential macrominerals, essential microminerals, and environmental microminerals, as well as on the different individual minerals within each group. The effect of herd-date within class of HP (high-HP vs. low-HP) represented a variable proportion of total variability in the milk mineral content, which differed according to the individual minerals, ranging from 11 to $12 \%$ for $\mathrm{Na}$ and $\mathrm{K}$ to $91 \%$ for Sn (Table 2). Given that herd grouped together several management factors (i.e., housing conditions, feed supplements and diet quality, water quality, milking procedure and equipment), as well as the herds' different geographical areas, the percentage of variability explained by this factor appears to be low for the majority of macrominerals and for the majority of essential microminerals (Se excluded) and very high for all environmental microminerals. This finding means 
that the variation in the macromineral content of milk is basically controlled by individual animal factors (e.g., breed, genetics, parity, stage of lactation, health status), while herd (e.g., diet, water, soil, facility materials) plays a much more important role in determining the concentrations of environmental micro-elements in milk (B, Si, Sr, and Sn). However, environmental micro-elements do not play a specific role in animal metabolism and therefore are not strictly regulated in terms of absorption, retention, and excretion (Klasing et al., 2005). Practical diets used in this study area would not be expected to result in severe deficiencies of any of the essential elements. Most essential elements can be toxic when consumed in large amounts, which is only occasionally a problem for dairy cattle (NRC, 2001) and even less so for human health. Moreover, the possibility exists that the variability in the availability of one mineral could affect the absorption and metabolism of other minerals because they compete for some common digestive and metabolic pathways (Goff, 2018).

Essential macro- and microminerals are administered to animals mainly through supplementation, and the amount given with diet, mineral blocks, or both affects the content in milk, although the concentrations of some of them (i.e., Ca, P) are strongly regulated by animal factors (Gaignon et al., 2018). Of the macrominerals and essential microminerals, $\mathrm{Na}, \mathrm{Mg}, \mathrm{K}, \mathrm{Ca}, \mathrm{Fe}$, $\mathrm{Cu}$, and $\mathrm{Zn}$ were only mildly influenced by herd-date $(<25 \%)$. In fact, $\mathrm{Mg}$, Ca, and $\mathrm{Zn}$ bind to casein micelles in milk, so their variation is correlated with casein content, while $\mathrm{Na}$ and $\mathrm{K}$ are involved in maintaining the osmotic equilibrium between blood and milk (Holt, 2011), so the small effect of herd-date was expected. In the case of $\mathrm{Mg}$, this element follows the metabolism of $\mathrm{P}$ and $\mathrm{Ca}$, consistent with the correlations reported by Pilarczyk et al. (2013).

In their very large genetic study on 1,948 Dutch Friesian cows, van Hulzen et al. (2009) included herd (n $=398$ ) as a random effect in the model and found a modest effect of herd for $\mathrm{Mg}, \mathrm{K}, \mathrm{Ca}$, and $\mathrm{Zn}$ (from 13 to $24 \%$ of phenotypic variance), similar to that found here (from 11 to $22 \%$ ) and a very high herd effect for Se $(65$ vs. $49 \%$ ). They postulated that herd variance resulted from differences among the herds in housing, especially feed, and it is known that the Se content in milk is directly proportional to the organic Se content in the feedstuffs (Ceballos et al., 2009; Meyer et al., 2014)

Only in the case of $\mathrm{P}$ content of milk did we find a herd effect (41\%) larger than that observed in the Dutch Holstein population (15\%). In this case, the significant superiority of $\mathrm{P}$ content of milk from high-HP farms $(+5 \%)$ could be related to the greater $\mathrm{P}$ concentration $(+5 \%)$ observed in diets fed to lactating cows at modern farms compared with traditional farms in the same study area (Schiavon et al., 2019).

Notably, with the exception of S, only minerals with a low proportion of variability explained by herd-date $(\mathrm{Mg}, \mathrm{Ca}, \mathrm{Cu}$, and $\mathrm{Zn})$ were significantly affected by HP class (whose effect was tested on the herd-date variance); in all cases, the levels were higher in milk sampled from high-HP cows than in milk from low-HP cows (Table 2). It seems reasonable to assume that an important source of variation in these elements is the cows' diets, in particular the forage-to-concentrate ratio (much higher in low-HP herds) and mineral-vitamin supplementation, and also the different milk protein content between the $2 \mathrm{HP}$ levels (greater in high-HP herds).

The large effect of herd-date (from 34 to $41 \%$ of total variance) on the $\mathrm{P}, \mathrm{S}$, and $\mathrm{Mn}$ levels in milk could be explained by the fact that feedstuffs contain relatively high and variable amounts of these minerals (Meyer et al., 2014), especially S, for which the level in feedstuffs is related to protein concentration. The Mn content in feedstuffs is quite variable and is influenced by soil type and plant species (Hurley and Keen, 1987).

As previously seen, all environmental microminerals exhibited very high variability among the different herds and sampling dates. The available literature on these microminerals in bovine milk is now outdated, but their variability in milk could arise from their differing natural content in the feed and water consumed by cows, and may also be attributable to the different soil characteristics of the various valleys in the province where the samples were taken. A similar high variability among different farms was also observed for the environmental minerals contained in beef samples (Patel et al., unpublished data). Boron enters the environment mainly through the weathering of rocks, but also through fertilizers, while the major sources of $\mathrm{Si}$ are forages and cereal grains high in fiber (i.e., oats, barley) (Pennington, 1991). Most fresh feeds naturally contain less than $1 \mathrm{mg} / \mathrm{kg}$ of Sn (Greger, 1988), so little of this mineral is present in the diets of livestock. Even if contaminated, water is a valuable source of this element. In general, feedstuffs of plant origin, especially leguminous rather than gramineous forages, are rich sources of Sr (Klasing et al., 2005).

\section{Effects of Breed Within Herd}

Our study found that the breed of cow affected the levels of all essential macro- and microminerals in milk, with $\mathrm{Cu}$ being the only exception. A few studies have analyzed in detail the mineral profile of milk obtained from individual animals of several breeds (Hermansen et al., 2005; Buitenhuis et al., 2015), but none has ana- 
lyzed data only from multibreed herds and used a model corrected for herd productivity class, the effects of herd within class, and the cows' parity and DIM. Our study also showed that the main differences were not due to aptitude (specialized vs. dual-purpose breeds) but to the different breeds within purpose group, especially within the group of specialized dairy breeds.

A study by Barłowska et al. (2006) on 8 mineral elements in 147 milk samples from 5 breeds showed that milk from the Whiteback and Red native Polish breeds and from the Simmental breed contained higher amounts of essential macro-elements (K, Ca, Na, and $\mathrm{Mg}$ ) and some micro-elements ( $\mathrm{Zn}$ and $\mathrm{Fe}$ ) than milk from Polish Holstein-Friesian Black-and-White and Red-and-White varieties. In our study, we also found milk samples from Holstein-Friesian cows to have the lowest amounts of almost all the essential minerals.

More information is available on comparisons between 2 specialized dairy breeds, Holsteins and Jerseys. Hermansen et al. (2005) studied 51 mineral elements in 480 milk samples from Danish Holstein and Jersey cows and found that the Jersey milk was richer in $\mathrm{Ca}$, $\mathrm{P}, \mathrm{Cu}, \mathrm{Fe}, \mathrm{Mg}, \mathrm{Mn}$, and $\mathrm{Zn}$ than milk from the Danish Holstein breed. More recently, Buitenhuis et al. (2015) studied 10 mineral elements in 892 milk samples from cows of these same 2 breeds, and their results confirmed Jersey milk as having a greater content of all the minerals than Holstein milk, with the exception of $\mathrm{K}$. We also found Jersey cows' milk to have the lowest $\mathrm{K}$ content of all the breeds in our study. In their study of susceptibility to $\mathrm{Cu}$ toxicity, Du et al. (1996) found another difference between these 2 breeds: Jersey cattle on the same diet as Holstein-Friesians accumulated more $\mathrm{Cu}$ in their livers. It was not clear whether this finding reflected differences in feed intake, efficiency of $\mathrm{Cu}$ absorption, or biliary excretion of $\mathrm{Cu}$. In any case, the Jerseys had the best mineral profile, which could be explained in part by the higher protein (casein) and fat content in their milk. Calcium, S, and $\mathrm{Zn}$ are mostly bound to casein micelles (Neville et al., 1995), which could explain their greater concentrations in Jersey milk than in the 2 large-framed dairy breeds. The idea that milk composition could explain differences in the mineral profiles of milk from different breeds could also apply in comparisons of Holstein-Friesians with Brown Swiss. The Alpine breed is known to be superior in terms of casein fractions and mineral content (Malacarne et al., 2006).

With regard to dual-purpose breeds, Pilarczyk et al. (2013) studied the concentrations of 10 mineral elements ( 2 toxic heavy metals and 8 trace elements) in the milk of Simmental and Holstein-Friesian cows reared on organic farms. They concluded that the milk of the Simmental breed had a better mineral composition and a lower concentration of noxious metals than the milk of Holstein-Friesian cows. Our study also found that the macromineral profile of milk from Simmental cows was similar to that of milk from Brown Swiss cows and better than that of milk from Holstein-Friesian cows. As in the survey carried out by Barłowska et al. (2006), we also found that the 2 local breeds produced milk with a mineral profile similar to that of the Simmental breed.

\section{Direct and Indirect Effects of Breed}

Given the substantial differences among breeds and previous attribution of these differences to different milk compositions (Neville et al., 1995), it has been important to distinguish the direct effect of breed on the detailed mineral profile (independently of the effects on milk yield and composition) from the indirect breed effect, which is mediated by differences in milk yield and composition, and to quantify these effects. As we are unaware of any existing information in this regard, we tried to investigate this aspect by modifying the base statistical model we used by including milk yield, protein, fat, and SCS as general covariates and by calculating the breed variances (treated as a random factor) with and without covariates for each mineral trait. As shown in Figure 7, the proportions of direct and indirect breed effects were very different for the various minerals examined.

In our study, differences in milk yield and composition (indirect effect of breed) accounted for a large proportion of the total breed variance for $\mathrm{Mg}$, S, and $\mathrm{Ca}$ among the macrominerals (81 to $94 \%$ ) and for $\mathrm{Mn}$ and Zn among the trace elements (76 and 68\%, respectively). Breed had a much lower direct effect on $\mathrm{S}$ and Ca because these elements depend on available casein, while only $35 \%$ of $\mathrm{Mg}$ is bound to casein micelles (Gaucheron, 2005). Consequently, casein content might not be so important in determining $\mathrm{Mg}$ variation in milk. However, this element is present mainly as citrate and phosphate compounds and as free ions. About $67 \%$ of Mn in cows' milk is bound to casein, $1 \%$ to globular fat membranes, and $32 \%$ to the whey fraction, whereas less than $0.1 \%$ of total Se is bound to fat (Lönnerdal et al., 1985). In addition, 1 to $3 \%$ of $\mathrm{Zn}$ is bound to the lipid fraction, and the remainder is in the skim milk fraction. The influence of some minerals on technological properties of milk, particularly coagulation, curd-firming, and cheese yield, is known (Malacarne et al., 2006; Bittante et al., 2012). Recently, Sanchez et al. (2018) showed that high concentrations of $\mathrm{Ca}, \mathrm{P}$, and $\mathrm{Mg}$ in milk are associated with higher cheese yield, both fresh and in dry matter, and better coagulation properties. It could be interesting to address future research to the 


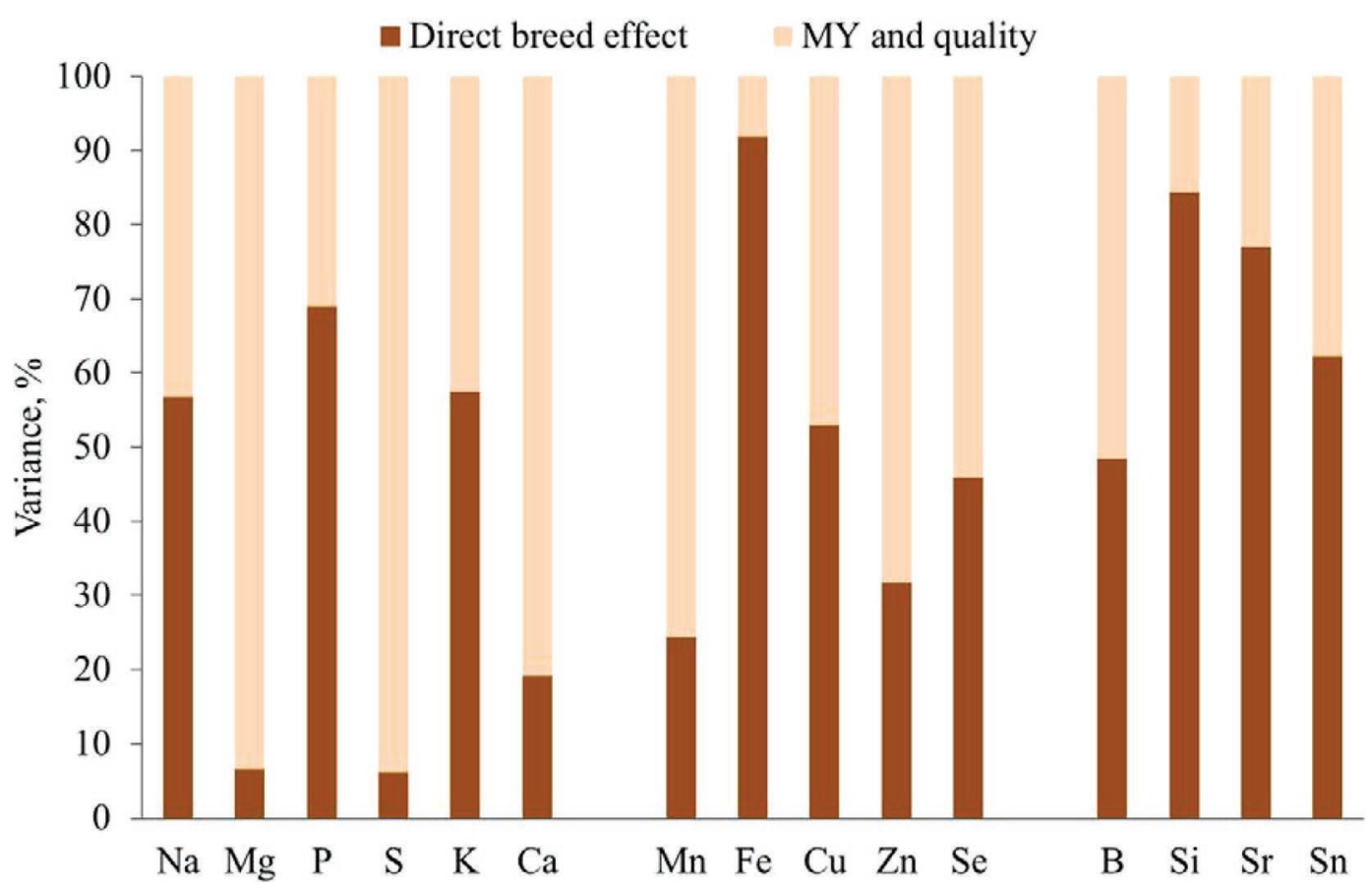

Figure 7. Proportion of total breed variance explained by direct breed effect independent of milk yield (MY) and composition, or by indirect breed effect represented by differences in milk yield and quality traits on macrominerals and essential and environmental microminerals.

quantification of the role of macro- and microminerals in explaining the breed differences in terms of cheesemaking aptitude of their milk.

The other essential minerals, excluding Fe but including the environmental $\mathrm{B}$, were found to depend on milk composition and yield and on the direct (independent) effect of breed in similar proportions (Figure 7). Iron was the only essential micromineral to not be much affected by milk yield and composition, as were the environmental micro-minerals, which also exhibited a specific independent effect of breed. These results on the direct effects of breed (thus mainly due to genetic factors) are consistent with findings from the study by $\mathrm{Du}$ et al. (1996) on different absorption levels of $\mathrm{Cu}$, Zn, and Fe in Jersey and Holstein-Friesian cows. Differences in the metabolism of trace elements between the 2 breeds have also been reported. Within the HolsteinFriesian breed, van Hulzen et al. (2009) demonstrated that genetics exert a fundamental role in explaining variability among individual cows. According to their estimates, intraherd heritability of 6 milk minerals ranged from 20 to $62 \%$. In any case, despite the technological advances in analytical methods (Lucey et al., 2017), the use of specific laboratory analysis is almost cost prohibitive for application at the population level, as well as being time consuming. On the other hand, for those minerals predicted with sufficient accuracy (i.e., Na, P, and Ca), Fourier-transform infrared spec- troscopy could be a good compromise between time and cost of analysis, and a useful tool, especially if applied in selective breeding programs in cows (Soyeurt et al., 2009) and in buffaloes (Stocco et al., 2016).

\section{CONCLUSIONS}

This study on multibreed herds allowed the effects of farm and breed of cow to be investigated independently. In particular, herd within farm productivity class had relatively little effect on the essential macrominerals, for which blood levels are strictly regulated ( $\mathrm{Na}, \mathrm{K}$, and, in part, $\mathrm{Mg}$ ), but had a greater effect on the other essential macro- and microminerals, and a very high effect on Se and the environmental microminerals. Comparison between farms with high and low average daily milk energy output revealed significant differences only in minerals with moderate variability in the effects of individual herd within productivity class. Breed remained a major source of variation for all essential minerals in milk, with $\mathrm{Cu}$ being the only exception. Major differences were noted within the dairy breeds, but not between specialized dairy and dual-purpose breeds. In particular, the results confirmed that milk from Jersey and from Brown Swiss (and dual-purpose) cows had much greater concentrations of almost all essential minerals (excluding $\mathrm{Na}$ and $\mathrm{K}$ ) than milk from Holstein-Friesian cows. Moreover, we showed that the combined effects 
of milk yield and composition explained a proportion of breed variance according to the mineral examined. This indirect effect of breed was greatest for $\mathrm{Mg}, \mathrm{S}, \mathrm{Ca}, \mathrm{Mn}$, and $\mathrm{Zn}$, and intermediate for $\mathrm{Na}, \mathrm{P}, \mathrm{K}, \mathrm{Cu}$, Se, and B. We considered it very important to try to ascertain why the concentrations of some of these minerals depended on milk yield and composition, and why others did not, as a basis for further understanding the genetic and physiological mechanisms regulating minerals in milk. In the case of $\mathrm{Fe}$ and the environmental microminerals, the breed effect did not seem to depend on milk yield and composition, nor did the direct effect of breed seem to be very important. We also consider it important to further investigate the relationships between the mineral profile of milk and cheese-making traits and cheese quality.

\section{ACKNOWLEDGMENTS}

The authors thank the Autonomous Province of Trento (Italy) for funding.

\section{REFERENCES}

Barłowska, J., Z. Litwińczuk, J. Król, and M. Kędzierska-Matysek. 2006. Fatty acid profile and minerals content in milk from cows of various breeds over spring-summer feeding period. Pol. J. Food Nutr. Sci. 56(1s):13-16.

Bittante, G., C. Cipolat-Gotet, F. Malchiodi, E. Sturaro, F. Tagliapietra, S. Schiavon, and A. Cecchinato. 2015. Effect of dairy farming system, herd, season, parity, and days in milk on modeling of the coagulation, curd firming, and syneresis of bovine milk. J. Dairy Sci. 98:2759-2774.

Bittante, G., M. Penasa, and A. Cecchinato. 2012. Invited review: Genetics and modeling of milk coagulation properties. J. Dairy Sci. 95:6843-6870.

Bobbo, T., P. L. Ruegg, G. Stocco, E. Fiore, M. Gianesella, M. Morgante, D. Pasotto, G. Bittante, and A. Cecchinato. 2017. Associations between pathogen-specific cases of subclinical mastitis and milk yield, quality, protein composition, and cheese-making traits in dairy cows. J. Dairy Sci. 100:4868-4883.

Buitenhuis, B., N. A. Poulsen, L. B. Larsen, and J. Sehested. 2015. Estimation of genetic parameters and detection of quantitative trait loci for minerals in Danish Holstein and Danish Jersey milk. Genetics 16:52.

Cashman, K. D. 2002. Macrominerals in milk and dairy products, nutritional significance. Pages 2051-2058 in Encyclopedia of Dairy Sciences. H. Roginski, P. F. Fox, and J. W. Fuquay, ed. Academic Press, London, UK.

Cashman, K. D. 2006. Milk minerals (including trace elements) and bone health. Int. Dairy J. 16:1389-1398.

Ceballos, L. S., E. R. Morales, G. de la Torre Adarve, J. D. Castro, L. P. Martínez, and M. R. S. Sampelayo. 2009. Composition of goat and cow milk produced under similar conditions and analyzed by identical methodology. J. Food Compos. Anal. 22:322-329.

Cecchinato, A., A. Albera, C. Cipolat-Gotet, A. Ferragina, and G. Bittante. 2015. Genetic parameters of cheese yield and curd nutrient recovery or whey loss traits predicted using Fourier-transform infrared spectroscopy of samples collected during milk recording on Holstein, Brown Swiss and Simmental dairy cows. J. Dairy Sci. 98:4914-4927.

Coni, E., A. Bocca, D. Ianni, and S. Caroli. 1995. Preliminary evaluation of the factors influencing the trace element content of milk and dairy products. Food Chem. 52:123-130.
Coni, E., A. Bocca, P. Coppolelli, S. Caroli, C. Cavallucci, and M. Trabalza Marinucci. 1996. Minor and trace element content in sheep and goat milk and dairy products. Food Chem. 57:253-260.

Cooke, D. R., and P. L. H. McSweeney. 2014. The influence of alkaline earth metal equilibria on the rheological properties of rennetinduced skim milk gels. Dairy Sci. Technol. 94:341-357.

Croghan, C. W., and P. P. Egeghy. 2003. Methods of dealing with values below the limit of detection using SAS. Presentation at Southeastern SAS User Group, St. Petersburg, FL. Accessed January 2019. https://analytics.ncsu.edu/sesug/2003/SD08-Croghan.pdf.

Du, Z., R. W. Hemkin, and R. J. Harmon. 1996. Copper metabolism of Holstein and Jersey cows and heifers fed diets high in cupric sulfate or copper proteinate. J. Dairy Sci. 79:1873-1880.

Gaignon, P., M. Gelé, C. Hurtaud, and A. Boudon. 2018. Characterization of the nongenetic causes of variation in the calcium content of bovine milk on French farms. J. Dairy Sci. 101:4554-4569.

Gaucheron, F. 2005. The minerals of milk. Reprod. Nutr. Dev. 45:473483.

Goff, J. P. 2018. Invited review: Mineral absorption mechanisms, mineral interactions that affect acid-base and antioxidant status, and diet considerations to improve mineral status. J. Dairy Sci $101: 2763-2813$

Greger, J. L. 1988. Tin and aluminum. Pages 291-323 in Trace Minerals in Food. K. T. Smith, ed. Marcel Dekker, New York, NY.

Gulati, A., N. Galvin, E. Lewis, D. Hennessy, M. O'Donovan, J. J. McManus, M. A. Fenelon, and T. P. Guinee. 2018. Outdoor grazing of dairy cows on pasture versus indoor feeding on total mixed ration: Effects on gross composition and mineral content of milk during lactation. J. Dairy Sci. 101:2710-2723.

Gustavsson, F., M. Glantz, A. J. Buitenhuis, H. Lindmark-Månsson, H. Stålhammar, A. Andrén, and M. Paulsson. 2014. Factors influencing chymosin-induced gelation of milk from individual dairy cows: Major effects of casein micelle size and calcium. Int. Dairy J. 39:201-208

Hamann, J., and V. Krömker. 1997. Potential of specific milk composition variables for cow health management. Livest. Prod. Sci. 48:201-208.

Hermansen, J. E., J. H. Badsberg, T. Kristensen, and V. Gundersen. 2005. Major and trace elements in organically or conventionally produced milk. J. Dairy Res. 72:362-368.

Holt, C. 2011. Milk salts - Interaction with caseins. Pages 917-924 in Encyclopedia of Dairy Sciences. 2nd ed. Academic Press, San Diego, CA.

Hurley, L. S., and C. L. Keen. 1987. Manganese in Trace Elements in Human and Animal Nutrition. 5th ed. W. Mertz, ed. Academic Press, Orlando, FL.

Huth, P. J., D. B. Di Rienzo, and G. D. Miller. 2006. Major scientific advances with dairy foods in nutrition and health. J. Dairy Sci 89:1207-1221.

ISO-IDF (International Organization for Standardization and International Dairy Federation). 2010. Milk-Determination of fat content. International Standard ISO 1211 and IDF 1:2010. ISO, Geneva, Switzerland; IDF, Brussels, Belgium.

ISO-IDF (International Organization for Standardization and International Dairy Federation). 2014. Milk and milk products-Determination of nitrogen content-Part 1: Kjeldahl principle and crude protein calculation. International Standard ISO 8968-1 and IDF 1:2014. ISO, Geneva, Switzerland; IDF, Brussels, Belgium.

Klasing, K. C., J. P. Goff, J. L. Greger, J. C. King, S. P. Lall, X. G. Lei, J. G. Linn, F. H. Nielsen, and J. W. Spears. 2005. Mineral Tolerance of Animals. 2nd rev. ed. Natl. Acad. Press, Washington, DC.

Lönnerdal, B., C. L. Keen, and L. S. Hurley. 1985. Manganese binding proteins in human and cow's milk. Am. J. Clin. Nutr. 41:550-559.

Lucey, J. A., D. Otter, and D. S. Horne. 2017. A 100-year review: Progress on the chemistry of milk and its components. J. Dairy Sci. 100:9916-9932.

Malacarne, M., P. Franceschi, P. Formaggioni, S. Sandri, P. Mariani, and A. Summer. 2014. Influence of micellar calcium and phosphorus on rennet coagulation properties of cows milk. J. Dairy Res. $81: 129-136$. 
Malacarne, M., A. Summer, E. Fossa, P. Formaggioni, P. Franceschi, M. Pecorari, and P. Mariani. 2006. Composition, coagulation properties and Parmigiano-Reggiano cheese yield of Italian Brown and Italian Friesian herd milks. J. Dairy Res. 73:171-177.

Malacarne, M., G. Visentin, A. Summer, M. Cassandro, M. Penasa, G. Bolzoni, G. Zanardi, and M. De Marchi. 2018. Investigation on the effectiveness of mid-infrared spectroscopy to predict detailed mineral composition of bulk milk. J. Dairy Res. 85:83-86.

Mariani, P., A. Summer, P. Formaggioni, and M. Malacarne. 2002. La qualità casearia del latte di differenti razze bovine. La Razza Bruna. 1:7-13.

Meyer, U., K. Heerdegen, H. Schenkel, S. Dänicke, and G. Flachowsky. 2014. Influence of various selenium sources on selenium concentration in the milk of dairy cows. J. Verbraucherschutz Lebensmsicherh. 9:101-109.

Neville, M. C., P. Zhang, and J. C. Allen. 1995. Minerals, ions, and trace elements in milk. A. Ionic interactions in milk. Pages 577592 in Handbook of Milk Composition. R. G. Jensen, ed. Academic Press, New York, NY.

NRC. 2001. Nutrient Requirements of Dairy Cattle. 7th rev. ed. Natl. Acad. Press, Washington, DC.

Pennington, J. A. T. 1991. Silicon in foods and diets. Food Addit. Contam. 8:97-118.

Perween, R. 2015. Factors involving in fluctuation of trace metals concentrations in bovine milk. Pak. J. Pharm. Sci. 28:1033-1038.

Pilarczyk, R., J. Wójcik, P. Czerniak, P. Sablik, B. Pilarczyk, and A. Tomza-Marciniak. 2013. Concentrations of toxic heavy metals and trace elements in raw milk of Simmental and Holstein-Friesian cows from organic farm. Environ. Monit. Assess. 185:8383-8392.

Sanchez, M. P., M. El Jabri, S. Minéry, V. Wolf, E. Beuvier, C. Laithier, A. Delacroix-Buchet, M. Brochard, and D. Boichard. 2018. Genetic parameters for cheese-making properties and milk composition predicted from mid-infrared spectra in a large data set of Montbéliarde cows. J. Dairy Sci. 101:10048-10061. https://doi .org/10.3168/jds.2018-14878.

Schiavon, S., E. Sturaro, F. Tagliapietra, M. Ramanzin, and G. Bittante. 2019. Nitrogen and phosphorus excretion on mountain farms of different dairy systems. Agric. Syst. 168:36-47.

Soyeurt, H., D. Bruwier, J. M. Romnee, N. Gengler, C. Bertozzi, D. Veselko, and P. Dardenne. 2009. Potential estimation of major mineral contents in cow milk using mid-infrared spectrometry. J. Dairy Sci. 92:2444-2454.

Spears, J. W., and W. P. Weiss. 2014. Invited review: Mineral and vitamin nutrition in ruminants. Prof. Anim. Sci. 30:180-191.

Stocco, G., C. Cipolat-Gotet, T. Bobbo, A. Cecchinato, and G. Bittante. 2017. Breed of cow and herd productivity affect milk composition and modeling of coagulation, curd firming and syneresis. J. Dairy Sci. 100:129-145.

Stocco, G.. C. Cipolat-Gotet, V. Bonfatti, S. Schiavon, G. Bittante, and A. Cecchinato. 2016. Short communication: Variations in major mineral contents of Mediterranean buffalo milk and application of Fourier transform infrared spectroscopy for their prediction. J. Dairy Sci. 99:8680-8686.

Stocco, G., C. Cipolat-Gotet, V. Gasparotto, A. Cecchinato, and G. Bittante. 2018. Breed of cow and herd productivity affect milk nutrient recovery in curd, and cheese yield, efficiency and daily production. Animal 12:434-444.

Summer, A., P. Franceschi, M. Malacarne, P. Formaggioni, F. Tosi, G. Tedeschi, and P. Mariani. 2009. Influence of somatic cell count on mineral content and salt equilibria of milk. Ital. J. Anim. Sci. $8: 435-437$.

Summer, A., M. Pecorari, E. Fossa, M. Malacarne, P. Formaggioni, P. Franceschi, and P. Mariani. 2004. Frazioni proteiche, caratteristiche di coagulazione presamica e resa in formaggio ParmigianoReggiano del latte delle vacche di razza Bruna italiana. Page 77-82 in Proc. 7a Conferenza Mondiale Allevatori Razza Bruna, Parma, Italy.

Tsiamadis, V., G. Banos, N. Panousis, M. Kritsepi-Konstantinou, G. Arsenos, and G. E. Valergakis. 2016. Genetic parameters of calcium, phosphorus, magnesium, and potassium serum concentrations during the first 8 days after calving in Holstein cows. J. Dairy Sci. 99:5535-5544.

van Hulzen, K. J. E., R. C. Sprong, R. van der Meer, and J. A. van Arendonk. 2009. Genetic and nongenetic variation in concentration of selenium, calcium, potassium, zinc, magnesium, and phosphorus in milk of Dutch Holstein-Friesian cows. J. Dairy Sci. 92:5754-5759.

Zamberlin, Š., N. Antunac, J. Havranek, and D. Samaržija. 2012. Mineral elements in milk and dairy products. Mljekarstvo 62:111-125. 